\title{
THE COGNITIVE STRATEGY OF POST-NEOCLASSICAL PHILOSOPHY OF HISTORY
}

\section{Dobrolyubska Yu. A.}

\section{INTRODUCTION}

The idea of inter-paradigm synthesis in the philosophy of history is still new and has not received a thorough justification in the scientific literature. Its setting can be found in some papers that discuss aspects of interdisciplinarity in historical science and the problems of historiographic synthesis. In this regard, its needed to highlight the works of the classics of French historical school "Annals" and A.Ya. Gurevich, O.M. Medushevskoyi, L.P. Repinoi, J. Tosha and some other authors. They lay the foundations of interdisciplinary cooperation in the field of social and humanitarian cognition (J. Tosh), discussing the topic of "historical synthesis" (A.Ya. Gurevich), "bridges" are built between traditional historiography and the latest epistemological "calls" of the philosophy of postmodernism (L.P. Repina). However, in whole, the question of whether it is possible, in the context of methodological pluralism, to reduce different cognitive practices to some discursive types or models, as well as to distinguish between each of them the standards of science inherent in each of them.

\section{The new concepts of cognitive strategy}

Let's try to distinguish and characterize the basic concepts of cognitive strategy and principles of scientific research offered by the post-neoclassical subsystem of the philosophy of history.

When implementing a scientific strategy, three principles are of particular importance - historicism, objectivism and holism.

There are three aspects to the principle of historicism. First, it is the recognition that each era is a unique manifestation of the human spirit with its inherent culture and values, and that there are major differences between our era and all previous ones. Therefore, the principle of historicism requires taking into account the differences between the past and the present, overcoming the notion that people of 
the past behaved and thought the same way we did. Secondly, it is the understanding that the task of the historian is not simply to uncover such differences, but also to explain them, immersing them in a historical context. The principle of historicism in this aspect suggests that the subject of historical research cannot be detached from the environment. Third, it is a requirement not to consider historical events in isolation, but to represent history as a process and a connection between events over time ${ }^{1}$.

The development of the principle of historicism in postneoclassical science is associated with criticism, on the one hand, of postmodernism and, on the other, classical, or "strict historicism". Postmodernists believe that historical reality is what we think of it, that is, the past emerges as the subjective presentation of the present. Therefore, they proclaimed that historicism is dead and can no longer be considered a serious intellectual current. According to the principle of "strict historicism", historical reality is what was in the past "actually". Therefore, the historian must, on the one hand, abandon any standards and priorities beyond the study era and, on the other, try to see events from the perspective of their participants. The historian's job is to interpret the past in his own criteria or, as G. Elton wrote, to "understand the problem from within".

Post-Neo-Classics also treat historical reality as something that occurred in the past that needs to be reconstructed as adequately as possible. In their view, this can be done in accordance with the principle of historicism, which is understood as recognizing independence and honoring the past. Unlike postmodernists, postneoclassicists believe that the principle of historicism ensures that scientific historical knowledge is confronted with socially motivated misinterpretations of the past, since the requirements of the present are the starting point for postmodern knowledge of the past. At the same time, post-neoclassicists believe that attempts to "speak with the voice of the past" also fail to validate the practice of historical inquiry. Post neoclassicists point out that "we never catch the true "essence" of a particular moment in history as it was experienced by people of that

1 Тош Д. Стремление к истине: Как овладеть мастерством историка. Москва: Весь мир, 2000. С. 18-20.

2 Юрганов А. Л. Источниковедение культуры в контексте развития исторической науки. Россия XXI. 2003. № 3. С. 71. 
time, because, unlike them, we know what happened afterwards and the importance we attach to one event or another, is inevitably driven by this knowledge. Whether we want it or not, the historian looks at the past "from above" - he already knows what it all ended with"3. To add, the position of the historian in the time relative to the object of study allows us to reflect on the past, to identify the preconditions that contemporaries did not suspect, and to see the true, and not desirable from the point of view of the participants' events.

The principle of "strict historicism" or "history for the sake of history" in classical science was synonymous with an impartial historical study, devoid of practical application. Post neoclassicists argue that strict adherence to the principle of "history for the sake of history" leads to the rejection of what makes history attractive, and a complete detachment from the present does not occur at all. Therefore, they believe that "in the face of virtually unlimited volume of data about human activities and the need to select some of the problems and periods that deserve more attention than any other historian has the right to allow important impact on society of their choice" 4 .

Specialists, of course, understand that the branches of history that claim to be connected with the present are more subject to manipulation by ideologues. But this should only increase the responsibility of historians, which is to "provide a historical perspective for bringing more scholarly discussion to modern debates rather than serving any ideology." Responding to the "appeal of the present", as D. Tosh points out, "does not mean to falsify or distort the past, it means to resurrect those aspects of the past that can tell us more right now"5.

Without abandoning the claim to the practical significance of his work, post-neoclassical historical science insists on the priority of authentic reproduction of the past. It proceeds from the reality of its existence and the possibility of objective cognition of it, so another important principle of the cognitive strategy of post-neoclassical philosophy of history is the principle of objectivism. In this case, postneoclassicists, on the one hand, continue the traditions laid down in

\footnotetext{
${ }^{3}$ Тош Д. Стремление к истине С. 168.

${ }^{4}$ Тош Д. Стремление к истине. С. 36.

5 Тош Д. Стремление к истине. С. 52.
} 
classical science, and on the other - claim a new interpretation of this principle.

In classical science, the principle of objectivism was based on the primacy of subject-object dichotomy and the need to reconstruct the history of "what it really was" through true (verification wise) theory and scientific methods of historical research. The classics believed that historical knowledge, being the result of the interaction of subject (historian) and object (historical reality), is able to adequately reflect this reality in itself, existing outside the culture and social order to which the researcher belongs, and expressed in language. At the same time, they believed that truth was beyond culture, social order and language, since objective historical reality itself selects its true descriptions and explanations, and the word only ensures the truth in historical knowledge.

Post-neoclassicists also believe that the basis of the principle of objectivism is the recognition of the past as an objective reality and the possibility of obtaining scientific knowledge adequate to historical reality. At the same time, they claim a new understanding of historical objectivity as the relationship of mutual dialogue between the subject under study and the subject under investigation. If the classics of the pledge of objectivity are seen in the neutrality of the subject of study in relation to its subject, then the post-neoclassicists believe that no one has yet managed to get rid of the "idols" of their own consciousness, and therefore historical knowledge always carries a subjective imprint of the era and individual culture. historian. In the subjective view of history, as T. Shanin points out, "of course, their "idols", which must be kept in mind, are laid - especially the danger of losing the vision of the importance of the "objective" in its connection with the "subjective" and "intersubjective," the danger of slipping into positions that make knowledge the only criterion for the causality of the historical process" $"$. However, this does not eliminate the need to strive for objectivity, that is, to adequately reproduce the past.

Post-neoclassicists, on the one hand, believe that historical knowledge is the result of interaction between the researcher and the

6 Шанин Т. Корни инакости. Иное. Хрестоматия нового российского самосознания / ред.-сост. С. Б. Чернышев. Т. 4: Путеводитель. Москва : Аргус, 1995. C. 31. 
subject under study, and that the words are capable of "articulating the various forms of contact of the knowing subject with the objects of historical study"7. On the other hand, they recognize that language is a convention, and historians use rhetorical strategies to recreate the past. Therefore, post-neoclassicists are ready to learn from postmodernists how to look for hidden content and contradictions in texts, but they do not agree that language is absolutely unstable and that it is not capable of expressing meaning. In this connection T. Shanin writes: "They (postmodernists. - Y. D.) very well show that in our knowledge and in life it has not happened, and further they conclude that nothing we can and cannot come out. That's something I don't agree with. There is nothing impossible. There is only the hard",

It should be noted that some post-neoclassicists believe that there is no irreconcilable contradiction between the question of the role of language in historical cognition between them and postmodernists, since postmodernists do not deny the existence of non-textual reality, but only doubt the possibility of its cognition. In particular, G. Spiegel attempts to prove the opposite with the help of the modern notion of mediation. She emphasizes that comprehension of historical data is always textual. In this regard, the historian either pushes away from the postmodern idea that language constructs the world, or is based on the approach of instrumentalism, according to which language, which both "invents" and describes reality, creates a tool of mediation between human consciousness and the known world. For the historian, according to G. Spiegel, the version of instrumentalism is much more important, because, unlike, say, a literary critic, he has no "stories" already written. In doing so, she insists that, although ideas about the social world are shaped by language, language itself is dependent on the social societies it uses and in which it is created. Spiegel also states that each text has its own "social logic" and its presence implies our ability to "recreate some sense of the material world of the past." This gives the researcher confidence in the ability of the language to provide information about historical life forms, since otherwise we

7 Appleby J., Hunt L., Jacob M. Telling the Truth about History. New York, London: W.W. Norton \& Company, 1994. p. 221.

${ }^{8}$ Шанин Т. Корни инакости. С. 34. 
would never be able to feel that we know anything about the past at all ${ }^{9}$.

Here one can see a turn from J. Derrida's radical position with his rejection of non-textual reality to the concept of F. de Saussure, who acknowledged the presence of both meaning and meaning in the text. But Spiegel does not call for the abandonment of the deconstruction of historical texts, which helps to "identify the ways in which texts deliver ideological hoaxes", as well as to identify and expose these hoaxes. In addition, she recalls that deconstruction has taught historians to pay close attention to the defaults that play an important role in the creation of texts. This combination of semiotics with the ways of deconstructing reading enriches our understanding of the past, it appears to be something more than a mere set of discursive strategies and phenomena. Although the existing connection of thought, language and action is difficult to explain, access to the past opens up an analysis of the intertwined discursive and social practices. Therefore, according to G. Spiegel, postmodernism helps to extend the historiographic practice without resorting to ideological extremism ${ }^{10}$.

In this regard, the post-neoclassicists claim that there is some connection between the past and the historian's view. At the same time, as the object of historical research, we distinguish between the past as past (and change the world in a certain way) and the past as present in the present with the help of our memory, as a reflection of this change in the world. This second "past" is used to construct a historical perspective and a retrospective, a picture of history. This use is possible thanks to the first past, namely the objectivity of the changes that have happened in the past and which are now the conditions of our lives ${ }^{11}$.

Considering the problem of objectivity in the context of the dialogue between the historian and historical reality, some of the postneoclassicists, following M. Bakhtin, present this dialogue as a discourse in which expressions and historical reality produce each

${ }^{9}$ Spiegel G. M. History and Postmodernism. The Postmodern History Reader / ed. by K. Jenkins. London; New York : Rutledge, 1998. P. 266.

10 Юдельсон А. В. Реферат: The Postmodern History Reader. Образы историографии. Москва : РГГУ, 2001. С. 312-313.

11 Смолина А. Н. Глубина времени, поверхность истории и проблема объективности события Историческое знание и интеллектуальная культура: материалы научной конференции. Москва, 4-6 декабря 2001 г. С. 36. 
other $^{12}$. In this regard, the problem of historical objectivity begins to take on an ethical character, and the "ethical core" of the profession of historian is the belief that his tedious work can bring authentic information about a dead "other" that does not come down to his own fantasies.

In this case, the desire to discover the objectivity of historical events can be seen as a flip side of the desire to avoid limitations and distortions in the interpretation of history. "This fear of misrepresentation of history (conscious or unconscious) is, as A.M. Smolina believes, the key to the question of what is at stake in objectivity, which means this impulse to "investigate" and to test the adequacy of one's own the past. It is obvious that the fear of distorting the notion of the past is not directed to the past: it is the fear that the misrepresented past will distort the future, make it "untrue", that the truth of the past will be lost in the past and will not be able to pass into the future, to be preserved for the future"13.

Post-neoclassicists disagree with postmodernists in that scientific discourse reflects only our own concepts and constructs, and the historical reality itself has a very weak referential status. At the same time, considering scientific dialogue as a discursive modeling of historical reality, she acknowledges that epistemological filters that mediate the interpretation of its subject matter are of great importance in historical research ${ }^{14}$. In this regard, scientific dialogue is seen as an expression of ontological connection in the historical study of the objective and subjective, carried out by means of simulacra or patterns of different levels. This idea is based on the idea that the past existed objectively, but we can only learn about it through our vision of historical reality. In this sense, we are dependent on the "glasses" we use to perceive the world, on the so-called "organized myths" that have been called McNeill's "myth-stories", without which we have nothing to say ${ }^{15}$.

\footnotetext{
12 Юдельсон А. В. Реферат. С. 306.

${ }^{13}$ Смолина А. Н. Глубина времени. С. 37.

14 Мальковская И. А. Россиеведение: между символом и симулякром. Россия и современный мир. 2003. № 1. С. 79.

${ }_{15}$ McNeill W. J. Mythistory and Other Essays. Chicago : University of Chicago Press, 1986. 226 p.
} 
Post-neoclassicists draw attention to the fact that, when studying historical reality, the researcher does not "communicate" directly with her, but creates an imaginary image of this reality, and then works with it. Theoretical constructions, which reflect images of historical reality, and were called simulacra. There are, as V. P. Kultigin points out, "different degrees of coincidence of simulacrum with reality. Completely simulacrum never coincides with reality. This coincidence may be close to the true state of affairs, and may be completely opposite in meaning. The simulacrum may have nothing to do with reality at all. Thus, our understanding of reality, our social reflection, are always mediated by these simulacra. It follows that there are no concepts that would not be plural; that all universals are separate; and that there are a plurality of universals" $"$.

Patterns are also images of historical reality and cognitive "prisms" through which researchers look at this reality as a whole (macropaterns) or its individual fragments (miso and micropaterns). In the research practice, patterns are theoretical and methodological advantages that allow to represent the historical reality and present the idea of the researcher himself.

The Post-Classical system argues that historical reality can be viewed through the prism of different patterns. In this respect, the patterns are "equal, equally legitimate and independent", historians do not choose them as much as they prefer. Therefore, in the understanding of patterns, "truth is not important, but authenticity, that is, the author himself thinks of all this, how and by what means he convinces us in his rightness"17. The diversity of patterns creates a problematic field of tension in historical science, generates scientific debate as the most important condition for its self-development.

This interpretation of the principle of objectivism through the relationship of mutual dialogue between the historian (subject) and historical reality (object) provides an opportunity to understand not only why different points of view are constantly competing in historical science, but also why each generation rewrites history.

Noting that historians constantly overestimate the past and rewrite history, some contemporary scholars see this as a peculiar feature of

${ }^{16}$ Култыгин В. П. Классическая социология. Москва : Наука, 2000. С. 466.

17 Гречко П. К. Концептуальные модели истории: Пособие для студентов. Москва : Логос, 1995. С. 19. 
historical knowledge. In their view, this is because the passage of time helps us to "move back" from the events of the past to a certain distance and to see, to reveal in them those connections, which we could not notice before. "Time, as noted by V. A. Lectorsky, not only reveals new connections and relationships between events, but often forces us to see differently the significance of certain facts of the past. In addition, our general understanding of the individual and society is changing. And in light of these new ideas, we begin to see in the past what we have not seen before. It is not in vain that contemporaries cannot understand the true meaning of what is happening in their eyes" $^{\text {"18 }}$.

Rewriting history also happens because each generation has a dialogue with the past in its own way, in terms that are meaningful to that generation. However, as stressed by G. A. Bordugov, "the need for each generation of historians to rewrite history again, though, and nullifies the old positivism, however, does not make it less objective. However, the historian - a qualified researcher - is not required to be the impersonal seeker of truth, who does not take into account himself, his character, his nationality, gender, etc. The realization of one of these is already a revolution. The pursuit of scientific neutrality and objectivity must not take the form of religion, and therefore of a new absolutism"19.

In modern research practice, the problem of objectivity of the past, that is, an adequate interpretation of historical reality, arises as a search for objective truth. Unlike those who claim that true epistemology is an intellectual anachronism, post-neoclassicists believe that the concept of truth is an attribute of scientific historical inquiry. This "objective truth" post-neoclassicists call such scientific knowledge, which is adequate to the subject of study and, accordingly, does not depend on the cognitive abilities and cognitive activity of the researcher. However, the search for such objective truth, which sets the strategic orientation of the scientist, is a rather problematic process. This is due to the fact that to represent "knowledge as"

18 Лекторский В. А. Эпистемология классическая и неклассическая. Москва : Эдиториал УРСС, 2009. С. 245.

19 Бордюгов Г. А. Вместо заключения. Каждое поколение пишет свою историю. Исторические исследования в России. Тенденщии последних лет. Москва : АИРО-ХХ, 1996. С. 432. 
reflection "of the characteristics of the object, then" reflection "is far from similar to the mirror. Science "reflects" its object, creating ideal conceptual systems that can be regarded as knowledge of a particular object only when they are subject to object interpretation. These theoretical constructs have their own logic of construction, different from the structure of their objects, which determines the limits of adequacy of the theoretical model to their object ${ }^{20}$.

When such boundaries are revealed, for example, in the case of a theory mismatch with historical facts, then researchers begin to search for or develop new theoretical constructs. However, establishing a correspondence between the facts and the new theory does not mean that the boundary of this theory of the subject of study will not be revealed again, and everything will not be repeated anew: the pursuit of adequacy through the creation of more effective theoretical tools. The problem of an adequate (complete and accurate) reconstruction of historical reality is manifested in theoretical pluralism, which is due to the fact that historical theories are different interpretations of available historical facts. Each of them, being a reconstruction and explanation from a certain point of view of some set of historical facts, may appear to be contrary to other reconstructions and cannot claim the status of scientific truth similarly, for example, to natural-scientific theories. However, the totality of such reconstructions, while recreating an increasingly diverse picture of the historical past, as well as including the past in the context of the problems, tasks, debates of the present day, may claim the status of historical truth ${ }^{21}$.

On the whole, the question of what is to be considered true in historical science is post neoclassicism translated into the plane of ideas about the heuristic possibilities of its various epistemological images, which contain stipulated criteria of scientificity and meet the requirements of modern mental communications.

20 Зотов А. Ф. Истина. Глобалистика. Москва : Диалог, Радуга, 2003. C. 415-416.

21 Зуев К. А. Следует ли считать архаизмом понятие научной истины? Общественные науки и современность. 1995. № 6. С. 127. 


\section{Principles of post-neoclassical research subsystems of the philosophy of history}

Thus, the post-neoclassical subsystem operates with a correspondent concept of truth. However, scientific truth becomes always contextual and ascertained, subject to the adoption of methodological postulates, on the basis of which a specific research situation is constructed. In historical studies, the search for scientific truth is always linked to either the study of specific historical events or the construction of historical theories. Both approaches solve the problem of objectivity in their own way: the theoretical history seeks to reveal the truth, purified from specific features, and the history of events wants to reveal the truth, given in the fullness of the nuances of a particular event. Based on the correspondent conception of truth, post-neoclassicists seek to reconstruct historical reality "in all its fullness, concreteness, and complexity."The main task of the researcher, in their opinion, is to "find out the significance, to explain and to clarify the meaning of history - this triumvirate of historical truth that breaks through the work of historians, despite the skepticism inherent in the modern era" 22 .

In pursuit of scientific truth, the historian uses this form of narrative as a historical narrative. With his help, the researcher tries to create in the readers the illusion of immediate presence, recreating the atmosphere and arranging historical scenery. Like other forms of storytelling, writes D. Tosh, "Historical narrative can be fun with the ability to keep the reader engaged and evoke intense emotions. But narrative is also an important method for the historian when he presents the material as if he were a participant in events of the past or as if he were observing them from the outside" ${ }^{23}$. The new subsystem recognizes that views on the past may be different, so it is necessary to constantly expand the base of sources of historical research and improve their tools, without which it is impossible to create an adequate empirical basis for historical science. In addition, historical sources must be continually re-examined by various researchers to identify conscious or unintentional distortions of historical reality. This will allow us to determine, in a multivariate, diverse history, a more adequate perspective on competing perspectives on the past.

\footnotetext{
${ }^{22}$ Appleby J., Hunt L., Jacob M. Telling the Truth about History. P. 276.

${ }^{23}$ Тош Д. Стремление к истине. С. 131.
} 
Another cognitive principle of post-neoclassical philosophy of history is holism, although some say that the idea of history as a whole can only be the subject of speculative philosophical reflection. In postneoclassical science, this principle directs the historian, on the one hand, to the need for a holistic study of the object of study, and, on the other, to the study of historical reality as a hierarchy of "wholeness" that does not boil down to the parts of which it is composed. It is emphasized that a sense of the whole as a context must always be present in the understanding of these parts. The principle of holism seeks to restore the level of claims of historical science to comprehend the past as a "holistic matter", woven of many multicolored threads, which fell sharply due to the spread in it of postmodern ideas. In connection with the actualization of the principle of holism in historical studies, post-neoclassicists raised the question of the need for global synthesis based on the integration of micro- and macrohistories, narratives and metatheories.

This principle is realized in the post-neoclassicists in the pursuit of a holistic vision of historical reality and the creation of a single toolkit for its study. Thus, the principle of holism in this sense applies not only to the subject of the study, but also to its methodology. Objectively, holism is realized specifically in the fact that history is seen as a complex social system and a set of humanitarian actions, as well as a super-active beginning. In addition to the general laws of the physical, social, and moral order governing the world, it is logical to allow the governing world to have single, and even exceptional, episodic dependencies.

In this regard, history as a natural systemic phenomenon nomological, it is associated with the manifestation of objective dependencies (from moral, cultural - to physical). History as a humanitarian phenomenon is connected with the activities of individuals and is bound to it: without individual personal actions there are no common historical actions. "From history, - emphasizes Ilyin, - to avoid neither nomology (legal correspondence), nor voluntariness (freedom of will of agents of action). The separation of voluntarism from nomologism gives a pseudo-historical doctrine, a stylization of a complete history". The hypertrophy of one and the other makes history a compendium of anecdotes, not science. The inadequacy of the subjectivist (voluntarism) and objectivist 
(nomologism) doctrines of history compels the search for new explicit heuristic schemes, such that would allow to carry out both principles adequately $^{24}$.

Therefore, the subject of history study should be not only social processes, structures and institutions, but also individual and collective actions of people, their ideas, values and attitudes. One who confines himself to analyzing global processes, thus refuses the fundamental proposition that they (especially in the phase of their emergence) are the result of individual and collective action. It is never forgotten that structures are born, changed and collapsed under their influence. Structures are always dependent on the person, no matter what their own dynamics, whatever imprint they, in turn, do not impose on the sphere of subjectivity, and as if they do not, as a result, coincide with the goals of people's actions or their life experience.

In this regard, the central role in the work of the historian is the interpretation of meaning, without which - writes D. Tosh - historical sources will not "talk", and we will never come close to understanding the past. The meaning of the text is considered as a sphere not only of individual but also of collective perception of the world. A key concept is culture as a system of perceptions that characterizes society and unites its members. It is a gigantic field of study that encompasses everything from the formal beliefs expressed in rituals and "rules of the game" to the unconscious logic of gesture and appearance.

Striving for holistic consideration of the subject of scientific research, post-neoclassicists distinguish in history structural dependencies of different levels, diachronic and synchronous sections, different systems. In particular, V. V. Ilyin distinguishes in the ontology of history: 1) structural dependencies of a distant order (megatrends), which are revealed by social phenology, fundamental rhythmodynamics (cyclical, rhythm of socio-historical structures, generation, restoration, elimination of socio-historical circumstances); 2) structural dependencies of the middle level (macro-tendencies) revealed by modular theories of society (types of state movements, soil impacts); 3) structural dependencies of the local level (microtrends), which are revealed by anthropological descriptions

${ }^{24}$ Лекторский В. А. Эпистемология классическая и неклассическая. С. 115. 
(actions of persons, scale of personal goals). D. Tosh believes that any historical situation can be regarded as the intersection of two planes. One of them can be called vertical (or diachronous) - it is a temporary sequence of previous manifestations of this activity. The other plane is horizontal (or synchronous), that is, the effect of different factors affecting a particular event at that moment.

In the subject field of historical research, I. Savelyeva and A. Poletaev distinguish three systems: 1) the system of the person (including mental and behavioral aspects of human existence), which generates the social world; 2) the social system that organizes this world; 3) a cultural system (including the products of material and spiritual culture) that ensures the functioning of the social world. In the social system, according to the types of social interaction, these scientists distinguish the economic, political and social subsystems. The internal environment for these subsystems is the system of everyday life, that is, everyday interaction. If the elements of the social system are the interaction of persons, then the elements of the cultural system are the products of the activity of persons. The cultural system encompasses ideal and institutional traditions, values and ideas, worldviews, ideologies and forms of expression, that is, symbolic understanding and interpretation of reality, through which not only oral and written, but in general, any type of communication is supported and accumulated.

Post-Classical history becomes both causal and casual. Therefore, in the subject of historical research, the post-neoclassical subsystem proposes to distinguish, on the one hand, various layers related to the influence of common and necessary causes, as well as to the influence of personal causes and free actions. On the other - to establish the relation of all this to the organization of man, because man in the acts of his activity, declaring freedom of will, duty, duty, self-glorification, transcends natural boundaries, goes beyond the established being.

In this regard, the question of the causality of historical events is characterized by a special multifaceted nature, reflecting the constant interplay of different spheres of human experience. D. Tosh believes that "at least, we must distinguish between common and immediate causes: the former have a long-term effect and localize a specific event, place it, so to speak, in the "flow" of history, the second 
predetermine its result, which often has a specific, totally unpredictable.

The multifaceted nature of causality in history requires the suspension of a consistent (chronological) account of events in order to weigh in turn all the factors relevant to the case, without losing sight of their relationship and the likelihood that the configuration of each factor changes over time. Therefore, post-neoclassicism emphasizes the limited nature of narrative narratives, especially in those areas of historical reality where "there may not be pronounced" protagonists "whose actions and reflections can be presented as narratives".

Finally, much attention is paid to the problem of long waves in history, its cycles and rhythms. Looking at the subject of historical science through the prism of long waves (cycles and rhythms) leads to the conclusion that the "ontological basis of history has two components": the initial beginning are human goals, motives, interests, values imposed on objective (subordinate). cyclic dependencies that have their own rhythm) conditions of life. Historical events because of this are multifaceted: the stench is generated by both individuals (lyceums) and objective dependencies, due to the inclusion of individuals in deeper causal relationships with definite historical cyclicality and rhythm. In this view of the subject of historical science, particular importance is attached to the phase transitions in history as a dynamic system that mutually anticipates both historical variability (development) and historical stability (preservation). In terms of historical reality, there are two types of phase transitions:

1. Phase transitions of the first kind - social mutations: at the point of the phase transition there is a release of civilian energy and a violent, frontal catastrophic change of forms of existence. Phase transitions of the first kind are under the banner of revolutions.

2. Second-Phase Transitions - Social Transformations: Nonviolent polymorphic transformations are recorded at the transition point due to laminar actions that repair the process. Second-order phase transitions include the Reformation. Phase equilibrium is characterized by a balance of forces in society.

The problem of long waves (cycles and rhythms) in history fits into the so-called "non-Markov paradigm", which is considered as the basis of one of the scientific pictures of the world. 
In the twentieth century, under the influence of physics, the scientific picture of the world, based on "Markov processes" or processes without consequences, was formed. "Markov processes" are random processes for which, at a known state of the system, its further evolution does not depend on the state of the system in the past. In other words, the past and future of the process are independent of each other in the fixed present. Therefore, knowing the state of the system at any point in time, one can only determine the probabilistic picture of system behavior in the future.

Nowadays, some scholars talk about the formation of such a scientific picture of the world, which is influenced by biology and the "non-Markov paradigm", under which they understand the system of ideas that describe processes with memory. According to these ideas in biological, economic, social phenomena cannot be neglected prehistory. Here the role of memory is very large, it directly influences the choice of the path of development. Processes that take place in the past are reflected in changes in structures. In terms of history, this means that the memory of the past, which is social information recorded in certain structures, determines not only the current state of the social system, but also the picture of its behavior in the future.

On the basis of the "non-Markov paradigm," the idea of society as a quasi-equilibrium system is drawn up, which includes a huge set of structural rhythms caused by the "recurrent nature of the change of the system, determined by the dependence on the past, on memory." Therefore, the study of the past, aimed at establishing in it a variety of rhythms (historical cycles) allows you to explain and predict the current and future behavior of social systems.

It should be borne in mind that from the standpoint of the "nonMarkov paradigm" the following phases of historical cycles "are not an exact repetition of the previous ones and may differ greatly from what was in the past. From this point of view, the pure progressive development of society does not seem to be the most likely". In this connection, as Azroyants, Kharitonov, and Shelepin write, "it is quite possible to imagine a cyclical course of history, for example, to imagine a scenario of a gradual return from a liberal-democratic society of modernity to a slave-owning one, but of course in a changed form. If physical forms of keeping slaves in obedience were 
used in antiquity, then in the future it may be effective to act directly on consciousness, allowing to manipulate people. The first manifestations of this possibility can be seen right now as a result of media action".

A characteristic feature of the post-neoclassical subsystem of the philosophy of history is the multifaceted consideration of historical reality. The first scale involves the study of individual actions and the historical facts they create; the second is specific historical events, processes and institutions whose complete coverage is not possible without certain procedures that capture movement across time and space; the third is universal historical events and processes. The various scales of consideration of historical reality correspond, as post-neoclassicists believe, to its very nature. Therefore, very dangerous attempts to declare this or that scale only real, and all the rest fictions. Such attempts lead to a distortion of reality, preventing the perception of its fullness and complexity.

In this regard, the principle of holism in post-neoclassical historical science involves taking into account the interweaving and interpenetration of realities of different scales in the space of history as a whole. The key task of the post-neoclassical subsystem of historical research is to build "differentiated models" of explaining the realities of the past, with subsequent synthesis of results and multiplescale interpretations.

Within the post-neoclassical subsystem of historical study, historians seek to study not only the behavior of individuals, but also the great events and collective changes that do not boil down to the totality of human aspirations. The creation of a scientific work is based on the assumption that a particular event is connected with what happened earlier, at the same time, and with what followed; in short, it is regarded as part of the historical process. Of particular importance, from the historian's point of view, are events that, in retrospect, have been important milestones in the process.

In this regard, post-neoclassical researchers note that "time and order of events in time are only one clue; the historian's job is also to find more significant connections between them than purely chronological ones". The historian must not only "slide" on the surface of historical events, but also introduce them into a broader temporal and value context, since "the transparent actions of people 
have opaque values that do not coincide with the vicissitudes of historical gravity. History seems to be broken down into an event history and a history of values. The first is fact-fixing, historiography, a chronicle of the self-evident routine of the natural flow of life. The second is understanding history, ideology, reflection of goals, values that exude over time. There are events in the chronicles, tendencies (annals, impersonal, transpersonal components of the course of things) remain in the annals. The ontology of history, it seems, consists of the actual and the super-factual, to which the inevitable dimension of activity belongs - a way of organizing life on innovative, effective principles. The double, unseen bottom of history is a realm of values that accumulates the quality of historical audacity and goes beyond empirical times.

According to the post-neoclassicist, a holistic vision of historical reality necessitates a comprehensive approach to its study. The successful implementation of this approach is associated with the use of historical research and quantitative analysis methods used, as a rule, in the study of supra-individual reality, and formal-logical methods in textology, which allow the study of databases using computer technology, and methods non-classical hermeneutics aimed at understanding the meaning of alien cultures.

Recognizing the need for not only subject but also methodological holism in historical science, post-neoclassicists again raised the question of the unification of scientific knowledge. They believe that the boundary between the social sciences and the natural sciences needs to be erased in the same way as the boundary between chemistry and biology. Such an attempt, in particular, was made by EA Wilson, who, in "Matching: Unity of Knowledge," showed that our understanding of the world and ourselves is determined by human nature, which evolved in the later interaction of genes and culture.

Considering the project of unification of scientific knowledge, P. Gross believes that it allows to fill in the gaps and establish relationships between different sciences, including the humanities cycle. In addition, in this project, $\mathrm{P}$. Gross sees not only a chance for a revival of more rigorous methods and criteria in science, but also a means of achieving more ambitious goals. Without the universals gained in science, we would only have many private perceptions of 
different peoples, including those to which we, of our own accord, belong.

\section{CONCLUSIONS}

The new post-neoclassical subsystem of the philosophy of history is in a state of its formation and development, but in our opinion it is already possible to give its primary characteristic from the standpoint of a systematic approach. We can state the creation of a new subsystem of the philosophy of history. The concept of this subsystem is the principles of historicism, objectivism and holism, the structure middle-level theory, the substrate - the category of "intertextuality" of the text and historical context.

Of course, generalizing the characteristics of a new subsystem of the philosophy of history would be much easier to write with broad strokes and post factum, when the scientific stream has already ceased to exist or became traditional, when a historical perspective has been formed, by which one can see the beginning and the end of its activity with the necessary a part of objectivity and quiet isolation.

But in the case of the post-neoclassical subsystem of the philosophy of history, it is much more complicated. We are dealing with a vibrant, very dynamic flow of philosophical and historical thought. It has recently emerged, continues to be active, and is provoking a lively and keen reaction from both supporters and adversaries - above all, like any innovation.

\section{SUMMARY}

The article describes the basic principles of scientific study of the post-neoclassical subsystem of the philosophy of history. Three principles: historicism, objectivism and holism. In the principle of historicism, there are three aspects: recognizing that each era is a unique manifestation of the human spirit with its culture and values; understanding that the task of the historian is not simply to uncover such differences, but also to explain them by immersing them in a historical context, since the object of historical research cannot be detached from the environment; requirement is not considered in isolation historical events and present history as a process and called the link between events in time. 
The basis of principle of objectivism is the recognition of the past as subjective reality and the possibility of scientific knowledge, adequate historical reality. Historical objectivism within this principle is understood as a relationship of mutual dialogue between the investigated object and sub object of which it investigates. Historical knowledge is always subjects subjective reflection of the era and individual culture historian, but this does not negate the need to desire about objectivity, adequate reconstruction of the past. As against facility historical research differs past as having passed (and changed the world in some way), and present the past as in the present with our memory memory. Treatment principle of objectivism's relationship through mutual dialogue between historian (subject) and historical reality (object) provides an opportunity to understand why historians are constantly competing points of view, and each generation rewrites history.

The principle of holism restores the claim of historical science to the comprehension of the past as a "coherent matter" and raises the question of the need for global synthesis on the basis of the integration of micro and macro history, narrative and metatheory. The PostClassical subsystem operates with a correspondent concept of truth. Scientific truth is always contextual and ascertained, subject to the adoption of methodological postulates, on the basis of which a specific research situation is constructed. In historical studies always search for scientific truth floor related to the study of Concrete $t$ are historical events or historical building theories. Both approaches solve the problem about objectivity: theoretical history tries to find the truth of Concrete cleared so they figure, and the history of events wants to reveal the truth, given in full nuances of a particular event. Based on the correspondent conception of truth, post-neoclassicists seek to reconstruct historical reality in its entirety, concreteness and complexity, and come to the third principle of post-neoclassical philosophy of history, the principle of holism. This principle directs the historian, on the one hand, to the need for a holistic study of the object of study, and, on the other, to the study of historical reality as a hierarchy of "wholeness" that does not boil down to the parts of which it consists. It is emphasized that a sense of the whole as a context must always be present in the understanding of these parts. 
We can state the creation of a new post-neoclassical subsystem of the philosophy of history. Concept of subsystems serve the principles of historicism, objectivism and holism, structure - theory mid-level, substrate - the category of "intertextuality" of the text and historical context.

\section{REFERENCES}

1.Тош Д. Стремление к истине: Как овладеть мастерством историка. Москва: Весь мир, 2000. 294 с.

2. Юрганов А. Л. Источниковедение культуры в контексте развития исторической науки. Россия XXI. 2003. № 3. С. 56-99.

3. Шанин Т. Корни инакости. Иное. Хрестоматия нового российского самосознания / ред.-сост. С. Б. Чернышев. Т. 4: Путеводитель. Москва : Аргус, 1995. С. 26-37.

4. Appleby J., Hunt L., Jacob M. Telling the Truth about History. New York, London : W.W. Norton \& Company, 1994. 322 p.

5. Spiegel G. M. History and Postmodernism. The Postmodern History Reader / ed. by K. Jenkins. London; New York : Rutledge, 1998. P. 257-272.

6. Юдельсон А. В. Реферат: The Postmodern History Reader. Образы историографии. Москва : РГГУ, 2001. С. 303-319.

7. Смолина А. Н. Глубина времени, поверхность истории и проблема объективности события Историческое знание и интеллектуальная культура: материалы научной конференции. Москва, 4-6 декабря 2001 г. С. 36-37.

8. Мальковская И. А. Россиеведение: между символом и симулякром. Россия и современный мир. 2003. № 1. С. 76-87.

9. McNeill W. J. Mythistory and Other Essays. Chicago : University of Chicago Press, 1986. 226 p.

10. Култыгин В. П. Классическая социология. Москва : Наука, 2000. 528 c.

11. Гречко П. К. Концептуальные модели истории: Пособие для студентов. Москва : Логос, 1995. 141 с.

12. Лекторский В. А. Эпистемология классическая и неклассическая. Москва : Эдиториал УРСС, 2009. 256 с.

13. Бордюгов Г. А. Вместо заключения. Каждое поколение пишет свою историю. Исторические исследования в России. Тенденциии последних лет. Москва : АИРО-ХХ, 1996. С. 427-436. 
14. Зотов А. Ф. Истина. Глобалистика. Москва : Диалог, Радуга, 2003. С. 415-416.

15. Зуев К. А. Следует ли считать архаизмом понятие научной истины? Общественные науки и современность. 1995. № 6. С. 125-127.

\section{Information about the author:} Dobrolyubska Yu. A., Doctor of Sciences in Philosophy, Professor, Head of the Department of World History and Methodology of Science,

South Ukrainian National Pedagogical University named after K. D. Ushinsky 26, Staroportofrankivska str., Odesa, 65020, Ukraine 